\title{
ISOLEMENT DU VIRUS DE LA MALADIE DE TALFAN EN FRANCE
}

\author{
P. GORET, B. TOMA et Y. RICHARD \\ Laboratoire de la Chaire des Maladies contagieuses, \\ École nationale vétérinaire, \\ 94701 Maisons Alfort
}

\section{RÉSUMÉ}

Quatre souches d'entérovirus du groupe I (Teschen-Talfan) ont été isolées à partir de petites enzooties de poliomyélite du Porc. La maladie et les lésions ont été reproduites chez le porcelet. La preuve est donc apportée de l'existence de la maladie de Talfan en France.

\section{SUMMARY}

ISOLATION OF THE TALFAN DISEASE VIRUS IN FRANCE

Four strains of the enterovirus of group I (Teschen-Talfan) have been isolated from small enzooties of swine polyomyelitis. The disease and its lesions have been replicated in the piglet. Thus, the existence of Talfan's disease in France is proved.

\section{RECHERCHES ÉPIDÉMIOLOGIQUES SUR LA MALADIE D'AUJESZKY EN BRETAGNE}

B. TOMA, Y. LE TURDU, R. ROSE, F. RENIER, C. DAVID, F. BERNARD et P. GORET

Laboratoire de la Chaire des Maladies contagieuses, École nationale vétérinaive 94701 Maisons Alfort

\section{RÉSUMÉ}

Une étude épidémiologique de la maladie d'Aujeszky chez le Porc, en Bretagne, est en cours. Elle porte sur la recherche des foyers de maladie avec isolement du virus (23 souches isolées entre I968 et octobre I972) et sur le dépistage de l'infection inapparente par mise en évidence d'anticorps neutralisants dans les sérums de verrats et truies prélevés au hasard dans les abattoirs. 